\title{
CPAP de $10 \mathrm{cmH}_{2} \mathrm{O}$ durante a circulação extracorpórea não melhora a troca gasosa pós-operatória
}

\author{
CPAP at $10 \mathrm{~cm} \mathrm{H}_{2} \mathrm{O}$ during cardiopulmonary bypass does not improve postoperative gas exchange
}

Luciana Castilho de FIGUEIREDO ${ }^{1}$, Sebastião ARAÚJO², Rosângela Cristina S. ABDALA ${ }^{3}$, Abrão ABDALA ${ }^{4}$, Cristina Aparecida Veloso GUEDES ${ }^{5}$

RBCCV 44205-976

\section{Resumo}

Objetivo: Comparar os índices de trocas gasosas no pósoperatório de pacientes submetidos a revascularização do miocárdio (RM) que receberam ou não pressão positiva contínua nas vias aéreas (CPAP) durante a circulação extracorpórea (CEC).

Métodos: Trinta pacientes adultos submetidos a RM com CEC no período de março a setembro de 2005 foram alocados aleatoriamente em dois grupos: $\operatorname{CPAP}(n=15)$, pacientes que utilizaram CPAP a $10 \mathrm{cmH}_{2} \mathrm{O}$ durante a CEC, e controle $(n=15)$, pacientes que não utilizaram CPAP. Foram analisados a $\mathrm{PaO}_{2} / \mathrm{FiO}_{2}$ e o $\mathrm{P}(\mathrm{A}-\mathrm{a}) \mathrm{O}_{2}$ em quatro momentos: Pré (logo antes da CEC, com $\left.\mathrm{FiO}_{2}=1,0\right)$; Pós (30min pósCEC, com $\mathrm{FiO}_{2}=1,0$ ); PO imediato (12h após a cirurgia, $\operatorname{com} \mathrm{FiO}_{2}=0,4$, utilizando máscara facial) e $1^{\circ}$ PO (24 horas após a cirurgia, com $\mathrm{FiO}_{2}=0,5$, utilizando máscara facial).

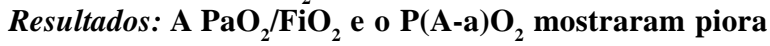

significativa no decorrer do tempo dentro de cada grupo, porém sem diferenças significativas entre os grupos em nenhum momento. Quando a $\mathrm{PaO}_{2} / \mathrm{FiO}_{2}$ foi subdividida em três categorias, foi observada maior prevalência de pacientes do grupo CPAP com valores entre $200 \mathrm{mmHg}$ e $300 \mathrm{mmHg}$ $(p=0,02)$ apenas no momento Pós (30min pós-CEC).

Conclusão: $\mathrm{O}$ uso de $\mathrm{CPAP}$ de $10 \mathrm{cmH}_{2} \mathrm{O}$ durante a CEC, muito embora tenha resultado em melhores valores na $\mathrm{PaO}_{2} /$ $\mathrm{FiO}_{2} 30$ minutos pós-CEC, não resultou em benefícios duradouros nas trocas gasosas durante o PO. Nós concluímos que, em pacientes submetidos a RM, a aplicação de CPAP 10 $\mathrm{CmH}_{2} \mathrm{O}$ não melhora significativamente as trocas gasosas pulmonares no pós-operatório.

Descritores: Pressão positiva contínua nas vias aéreas. Circulação extracorpórea. Troca gasosa pulmonar. Procedimentos cirúrgicos cardíacos.

1. Physiotherapist - Master; Physiotherapist - Intensive Care Unit, Hospital de Clínicas, Campinas State University and Doctoral Student - Surgery Department, Faculty of Medical Sciences, Unicamp.

2. Assistant Professor - Surgery Department, Faculty of Medical Sciences, Unicamp.

3. Physiotherapist, Unimed Hospital from Araras, SP.

4. Assistant Physician, Cardiac Surgery Department, Irmandade Santa Casa de Misericórdia from Araras, SP.

5. Physiotherapist, Master, Intensive Care Unit, Hospital de Clínicas, Campinas State University.

Work done at Universidade Estadual de Campinas e Centro Universitário Hermínio Ometto, Campinas, SP, Brazil.

Correspondence adress:

Luciana Castilho de Figueiredo

Rua Heitor Nascimento, 891 - Cidade Universitária, Distrito de Barão Geraldo - Campinas, SP, Brasil - CEP: 13083-800

E-mail: lucafige@ig.com.br 


\section{Abstract}

Objective: To compare postoperative (PO) pulmonary gas exchange indexes in patients submitted to myocardial revascularization (MR) with or without the application of continuous positive airway pressure (CPAP) during cardiopulmonary bypass (CPB).

Methods: Thirty adult patients submitted to MR with CPB between March and September 2005 were randomly allocated to two groups: CPAP $(n=15)$, patients that received CPAP at 10 $\mathrm{CmH}_{2} \mathrm{O}$ during $\mathrm{CPB}$, and control $(\mathrm{n}=15)$, patients that didn't receive $\mathrm{CPAP}$. $\mathrm{PaO}^{2} / \mathrm{FiO}_{2}$ and $\mathrm{P}(\mathrm{A}-\mathrm{a}) \mathrm{O}_{2}$ were analyzed at four moments: Pre (just before $\mathrm{CPB}$, with $\mathrm{FiO}_{2}=1.0$ ); Post (30min post-CPB, with $\mathrm{FiO}_{2}=1.0$ ); immediate $\mathrm{PO}$ period (12h postsurgery, with $\mathrm{FiO}_{2}=0.4$ by using a Venturi ${ }^{\circledR}$ facial mask) and first $\mathrm{PO}$ day (24h post-surgery, with $\mathrm{FiO}_{2}=0.5$ by a facial mask).

Results: $\mathrm{PaO}_{2} / \mathrm{FiO}_{2}$ and $\mathrm{P}(\mathrm{A}-\mathrm{a}) \mathrm{O}_{2}$ tend to get significantly

\section{INTRODUCTION}

Pulmonary complications associated to cardiopulmonary bypass (CPB) increase morbidity and mortality in patients submitted to cardiac surgeries [1]. The incidence of pulmonary complications varied largely and has been reported in $2 \%$ to $64 \%$ in patients submitted to open heart surgery with CPB, being characterized by an increase in the alveolar-arterial oxygen gradient $\left[\mathrm{P}(\mathrm{A}-\mathrm{a}) \mathrm{O}_{2}\right]$, atelectasis and increased alveolo-capilar membrane permeability [2].

The surgical opening of pleural cavity, with consequent loss of negative intra-pleural pressure, allied to the fact that the lungs remain directly in contact with the room air through the opened endotracheal tube are predisposing factors to atelectasis, increased intrapulmonary shunt, pulmonary congestion and alveolo-capilar membrane injury during open heart surgery with CPB. Pulmonary function and gas exchange are usually impaired in $20 \%$ to $90 \%$ of patients submitted to cardiac surgery with CPB. Pulmonary injury induced by CPB remains as an important cause of postoperative morbidity in these patients [3].

Many therapeutic strategies have been investigated in aim to minimize or prevent the incidence of these complications, including the vital capacity maneuver [4] and the application of continuous positive airway pressure (CPAP) during CPB [5].

CPAP maneuver is characterized by the application of a constant and continuous positive pressure into the patient's airway. In this manner, the flow generated by the mechanical ventilator keeps airways pressurized and opened, avoiding them to collapse [6].

Berry et al. [2] have reported that CPAP at $5 \mathrm{cmH}_{2} \mathrm{O}$ during CPB didn't improve pulmonary function (evaluated by alveolar-arterial oxygen gradient) and the extubation worst as time elapsed during the postoperative period in both groups, but no differences were observed between them at any moment. When $\mathrm{PaO}_{2} / \mathrm{FiO}_{2}$ was subdivided into three categories, a greater prevalence of patients with values between $200 \mathrm{mmHg}$ and $300 \mathrm{mmHg}$ were observed in CPAP group only at moment Post (30min post-CPB; $p=0.02)$.

Conclusion: CPAP at $10 \mathrm{cmH} 2 \mathrm{O}$ administered during $\mathrm{CPB}$, although had lightly improved $\mathrm{PaO}_{2} / \mathrm{FiO}_{2}$ at 30 minutes post-CPB, had no significant sustained effect on postoperative pulmonary gas exchange. We concluded that in patients submitted to $\mathrm{MR}$, application of $10 \mathrm{cmH}_{2} \mathrm{O} C P A P$ does not improve postoperative pulmonary gas exchange.

Descriptors: Continuous positive airway pressure. Extracorporeal circulation. Pulmonary gas exchange. Cardiac surgical procedures. time in their patients. Gilbert et al. [7] reported that the application of low CPAP levels during CPB has not statistically changed pulmonary mechanical properties or gas exchange in nine treated patients.

Magnusson et al. [8], in an experimental trial comparing pigs that have received or not CPAP at $5 \mathrm{cmH}_{2} \mathrm{O}$ during $\mathrm{CPB}$, reported that the application of CPAP didn't prevent atelectasis or increasing in pulmonary shunt in these animals when compared to control ones.

According to Loeckinger et al. [5], a negative fluid balance and the application of CPAP have been used to decrease the adverse effects of CPB on pulmonary function. The authors have applied CPAP at $10 \mathrm{cmH}_{2} \mathrm{O}$ during CPB in seven patients, verifying that those who received CPAP at $10 \mathrm{cmH}_{2} \mathrm{O}$ have shown improving in ventilation/perfusion mismatch, with lesser pulmonary shunt values and better gas exchange indexes measured four hours after CPB when compared to patients whose airways remained open to atmosphere.

In this way, considering the controversy surrounding this matter in medical literature, the main objective of the present trial was to evaluate the effects of CPAP at $10 \mathrm{cmH}_{2} \mathrm{O}$ applied during CPB on postoperative pulmonary gas exchange in adult patients scheduled to elective myocardial revascularization surgery.

\section{METHODS}

The study was approved by the Research Ethics Committee of the Faculty of Medical Science from Campinas State University (Unicamp) (protocol No 292/2005) and a written informed consent was obtained from every patient before inclusion.

The research was performed at the Irmandade de Santa Casa de Misericórdia from Araras (ISCMA), including 
surgical theater and intensive care unit settings, between March and September 2005.

The studied population was composed by 30 adult patients, both sexes, submitted to elective myocardial revascularization (MR) surgery with $\mathrm{CPB}$. This number of patients was initially selected based on data previously published $[2,5,8]$. During the trial period, all patients were managed by the same anesthetic and surgical teams, and no interference or modifications were done by the researchers in the pre-established anesthetic, surgical and clinical treatment guidelines.

Inclusion criteria were as following: age $\geq 18$ years; both sexes; elective surgical procedure; surgery with CPB and patient's voluntary agreement to participate in the research by sign an informed consent term. Exclusion criteria were: age $<18$ years; patients with valvulopathies associated to the ischemic heart disease; patients with left ventricle aneurysm; infective endocarditis; non-elective surgery and patient's refusal to sign the informed consent term.

The patients were randomly allocated in the day previous to surgery to two groups: CPAP group $(\mathrm{n}=15)$, with CPAP at $10 \mathrm{~cm} \mathrm{H}_{2} \mathrm{O}$ applied during $\mathrm{CPB}$, and control group $(\mathrm{n}=15)$, without CPAP during CPB.

Demographic data such as gender, age and body mass index (BMI), and the presence of actual tobacco use were recorded preoperatively. The type of surgery was also recorded. CPB time, mechanical ventilation time and arterial blood gases for oxygenation indexes calculations were extracted from anesthesia sheet, CPB sheet and patients ICU medical records, as appropriated.

In both groups, arterial blood samples for gas analyses $\left(\mathrm{PaO}_{2}, \mathrm{PaCO}_{2}, \mathrm{SaO}_{2}\right)$ and to pulmonary gas exchange indexes $\left[\mathrm{PaO}_{2} / \mathrm{FiO}_{2}\right.$ e $\left.\mathrm{P}(\mathrm{A}-\mathrm{a}) \mathrm{O}_{2}\right]$ calculations were collected at four different moments: Pre-CPB (just before $\mathrm{CPB}$, with $\mathrm{FiO}_{2}=1.0$ ); Post-CPB (30 minutes post-CPB, with $\mathrm{FiO}_{2}=1.0$ ); immediate $\mathrm{PO}$ (12 hours after surgery, with $\mathrm{FiO}_{2}=0.4$ by using a Venturi ${ }^{\circledR}$ facial mask); and at the first PO day (24 hours after surgery, with $\mathrm{FiO}_{2}=0.5$ by using a Venturi ${ }^{\circledR}$ facial mask).

\section{Statistical analysis}

Statistically, data were examined by using Qui-square or Fisher's exact test to compare categorical variables between groups. Mann-Whitney U test was used to compare numerical variables between groups at different observation moments. Analysis of variance for repeated measures (ANOVA) was used to compare pulmonary gas exchange variables between groups and between observation times. Comparisons between groups were done by using Tukey's post-hoc test, and comparisons between observation times were done by profile test. The variables without normal distribution were logarithmic $\left(\log _{10}\right)$ transformed for statistical analysis. P-values $<0.05$ were considered significant.
The study protocol diagram is shown in Figure 1.

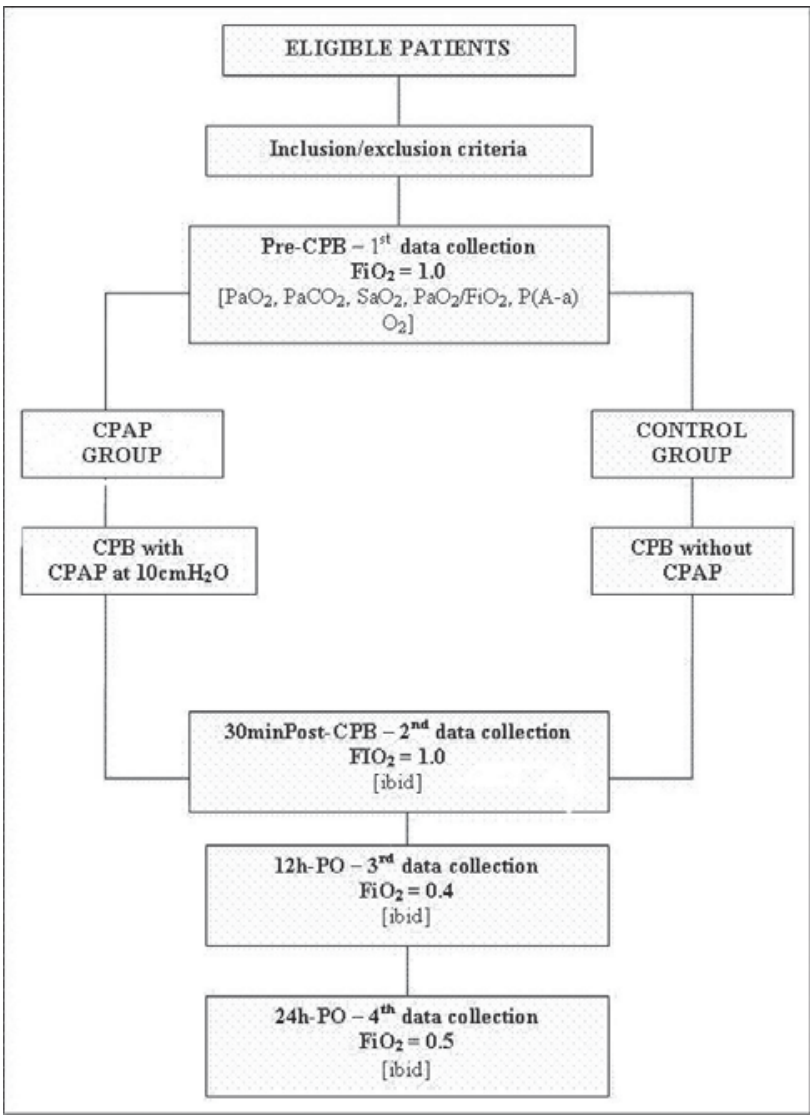

Fig. 1 - Study protocol diagram. - CPB = cardiopulmonary bypass; $C P A P=$ continuous positive airway pressure $; \mathrm{FiO}_{2}=$ inspired oxygen fraction; $\mathrm{PaCO}_{2}=$ arterial carbon dioxide partial pressure; $\mathrm{PaO}_{2}=$ arterial oxygen partial pressure; $\mathrm{PO}=$ postoperative; $\mathrm{SaO}_{2}=$ arterial oxygen saturation

\section{RESULTS}

Patient's demographic characteristics, CPB duration time and basal arterial blood gas values (Pré-CPB) are shown in Table 1. No significant differences were found between groups.

Post-operative mechanical ventilation times were 9.1 \pm 2.1 hours in CPAP group and $9.5 \pm 1.1$ hours in control group $(p=N S)$.

Statistically significant differences in $\mathrm{PaO}_{2} / \mathrm{FiO}_{2}$ and $\mathrm{P}(\mathrm{A}$ a) $\mathrm{O}_{2}$ were found by comparing their values at four different moments inside each group. However, no significant differences were found by comparing the two groups at any time (Tables 2 and 3 and Figures 2 and 3). 
Table 1. Basal data (Pre-CPB) of both groups (data, when pertinent, are expressed as mean \pm standard deviation).

\begin{tabular}{|c|c|c|c|}
\hline Variable & $\begin{array}{c}\text { CPAP Group } \\
\mathrm{N}=15\end{array}$ & $\begin{array}{c}\text { Control group } \\
\mathrm{N}=15\end{array}$ & $\begin{array}{c}\mathrm{P} \\
\text { value }\end{array}$ \\
\hline Gender (M/F) & $9 / 6$ & $12 / 3$ & NS \\
\hline Age (years) & $61.5 \pm 10.8$ & $60.5 \pm 9.3$ & NS \\
\hline BMI $\left(\mathrm{kg} / \mathrm{m}^{2}\right)$ & $26.8 \pm 4.0$ & $24.8 \pm 3.1$ & NS \\
\hline Tabagism (Yes/No) & $4 / 11$ & $6 / 9$ & NS \\
\hline CPB time (min) & $52.2 \pm 13.5$ & $56.9 \pm 20.8$ & NS \\
\hline $\mathrm{PaO}_{2}(\mathrm{mmHg})$ & $340.5 \pm 68.7$ & $334.5 \pm 120.3$ & NS \\
\hline $\mathrm{PaCO}_{2}(\mathrm{mmHg})$ & $41.0 \pm 9.8$ & $46.3 \pm 7.8$ & NS \\
\hline $\mathrm{SaO}_{2}(\%)$ & $99.9 \pm 0.3$ & $100.0 \pm 0.0$ & NS \\
\hline $\mathrm{PaO}_{2} / \mathrm{FiO}_{2}(\mathrm{mmHg})$ & $340.5 \pm 68.7$ & $334.5 \pm 120.3$ & NS \\
\hline $\mathrm{P}(\mathrm{A}-\mathrm{a}) \mathrm{O}_{2}(\mathrm{mmHg})$ & $273.6 \pm 116.9$ & $274.2 \pm 67.8$ & NS \\
\hline
\end{tabular}

$B M I=$ Body mass index $; C P A P=$ continuous positive airway pressure $; C P B=$ cardiopulmonary bypass; $F=$ female $; M=$ male; $\mathrm{PaO} 2$ = arterial oxygen partial pressure; $\mathrm{PaCO}_{2}=$ arterial carbon dioxide partial pressure; $\mathrm{PaO}_{2} / \mathrm{FiO}_{2}=$ oxygenation index; $\mathrm{P}(\mathrm{A}$ a) $\mathrm{O}_{2}=$ alveolar-arterial oxygen gradient; $\mathrm{SaO}_{2}=$ arterial oxygen saturation

Table 2. $\mathrm{PaO}_{2} / \mathrm{FiO}_{2}$ (mmHg) at different observation moments in CPAP and control groups.

\begin{tabular}{lccccc}
\hline Group & $\mathrm{PaO}_{2} / \mathrm{FiO}_{2}$ & Mean (SD) & Min & Median & Max \\
\hline \multirow{4}{*}{ Pre-CPB } & $341(69)$ & 213 & 351 & 441 \\
& Post-CPB & $256(83)$ & 165 & 230 & 418 \\
$\mathrm{~N}=15$ & $12 \mathrm{~h}-\mathrm{PO}$ & $256(51)$ & 182 & 242 & 380 \\
& $24 \mathrm{~h}-\mathrm{PO}$ & $210(46)$ & 164 & 192 & 292 \\
& Pre-CPB & $334(120)$ & 138 & 363 & 523 \\
Control & Post-CPB & $223(144)$ & 71 & 172 & 509 \\
$\mathrm{~N}=15$ & $12 \mathrm{~h}-\mathrm{PO}$ & $235(67)$ & 142 & 225 & 352 \\
& $24 \mathrm{~h}-\mathrm{PO}$ & $199(54)$ & 124 & 192 & 344 \\
\hline
\end{tabular}

Observation: comparison of $\mathrm{PaO}_{2} / \mathrm{FiO}_{2}$ (oxygenation index) between groups ( $p G$-value) $p G=0.183$; between times ( $p T$ value) $p T$

Table 3. $\mathrm{P}(\mathrm{A}-\mathrm{a}) \mathrm{O}_{2}(\mathrm{mmHg})$ at different observation moments in CPAP and control groups.

\begin{tabular}{lccccc}
\hline Group & $\mathrm{P}(\mathrm{A}-\mathrm{a}) \mathrm{O}_{2}$ & Mean (SD) & Min & Median & Max \\
\hline \multirow{4}{*}{ CPAP } & Pre-CPB & $274(68)$ & 176 & 269 & 412 \\
& Post-CPB & $352(79)$ & 195 & 381 & 440 \\
$\mathrm{~N}=15$ & $12 \mathrm{~h}-\mathrm{PO}$ & $126(35)$ & 77 & 125 & 233 \\
& $24 \mathrm{~h}-\mathrm{PO}$ & $187(20)$ & 144 & 193 & 211 \\
& Pre-CPB & $274(1167)$ & 92 & 258 & 464 \\
Control & Post-CPB & $379(140)$ & 101 & 434 & 524 \\
$\mathrm{~N}=15$ & $12 \mathrm{~h}-\mathrm{PO}$ & $124(28)$ & 84 & 118 & 178 \\
& $24 \mathrm{~h}-\mathrm{PO}$ & $189(29)$ & 112 & 187 & 237 \\
\hline
\end{tabular}

Observation: comparison of $\mathrm{P}(\mathrm{A}-\mathrm{a}) \mathrm{O}_{2}$ (alveolar-arterial gradient) between groups ( $p G$-value) $p G=0.827$; between times (pT-value) $p T$

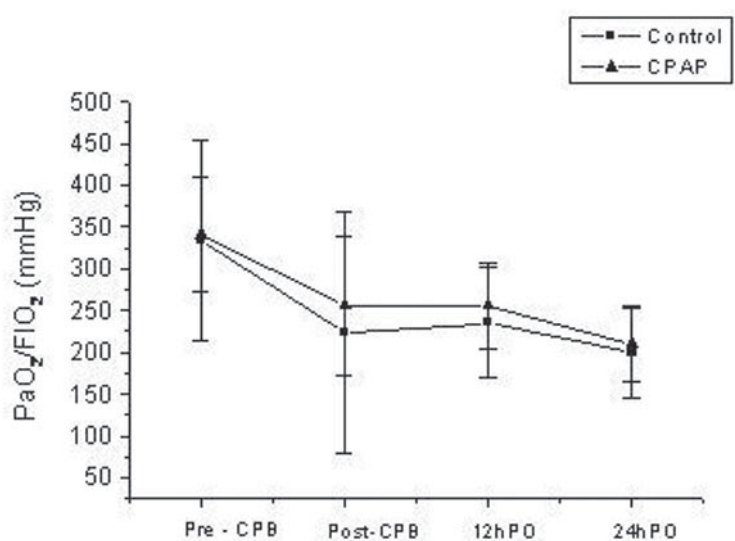

Fig. 2 - $\mathrm{PaO}_{2} / \mathrm{FiO}_{2}(\mathrm{mmHg})$ at different observation times. - $\mathrm{PaO}_{2}$ $\mathrm{FiO}_{2}(\mathrm{mmHg})$ at different observation times. Statistically significant differences were found between times for both groups. * $p T<$ 0.001 (Pre-CPB ““ 30minPost-CPB; Pré-CPB ““ 12h-PO; Pré$C P B$ “ “ 24h-PO; 12h-PO “ “ 24h-PO)

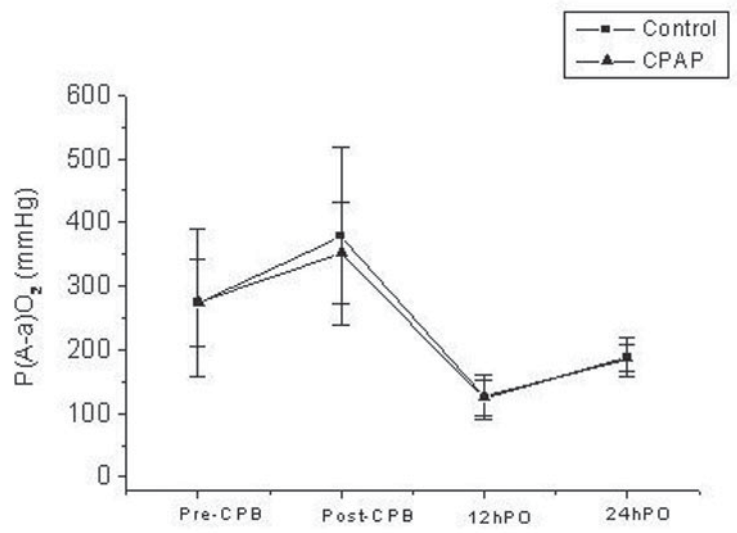

Fig. 3 - $\mathrm{P}(\mathrm{A}-\mathrm{a}) \mathrm{O}_{2}$ ( $\mathrm{mmHg}$ ) at different observation times. - $P(\mathrm{~A}-$ a) $\mathrm{O}_{2}(\mathrm{mmHg})$ at different observation times. Statistically significant differences were found between times for both groups. * $p T<0.001$ (Pre-CPB “ “ 30minPost-CPB; Pre-CPB “ “ 12h$P O$; Pre-CPB “" 24h-PO; 30minPost-CPB “" $24 h-P O$ and $12 h$ $P O$ ، “ 24h-PO)

When $\mathrm{PaO}_{2} / \mathrm{FiO}_{2}$ were subdivided into three categorical values, a greater prevalence of patients with $\mathrm{PaO}_{2} / \mathrm{FiO}_{2}$ between $200 \mathrm{mmHg}$ and $300 \mathrm{mmHg}$ was found in CPAP group at post-CPB moment (30 min post-CPB; $\mathrm{p}=0.02$ ) (Table 4 and Figure 4). 
Table 4. Distribution of patients (\%) according to categorical values of $\mathrm{PaO}_{2} / \mathrm{FiO}_{2}(\mathrm{mmHg})$ at different observation moments in CPAP and control groups.

\begin{tabular}{lcccccccc}
\hline $\mathrm{PaO}_{2} / \mathrm{FiO}_{2}$ & \multicolumn{4}{c}{ CPAP $(\mathrm{n}=15)$} & \multicolumn{4}{c}{ Control group $(\mathrm{n}=15)$} \\
\hline Moment & Pre-CPB & Post-CPB & $12 \mathrm{hPO}$ & $24 \mathrm{hPO}$ & Pre-CPB & Post-CPB & $12 \mathrm{hPO}$ & $24 \mathrm{hPO}$ \\
$<200$ & 0 & 26.7 & 6.7 & 53.3 & 13.3 & 73.3 & 33.3 & 53.3 \\
200 to 300 & 26.7 & $53.3^{*}$ & 73.3 & 46.7 & 26.7 & $0 *$ & 53.3 & 40.0 \\
$\geq 300$ & 73.3 & 20.0 & 20.0 & 0.0 & 0.0 & 26.7 & 13.3 & 6.7 \\
\hline
\end{tabular}

*Fisher's exact test ( $p$-value $=0.02)$. CPAP = continuous positive airway pressure; $C P B=$ cardiopulmonary bypass; $\mathrm{PaO}_{2} / \mathrm{FiO}_{2}=$ oxygenation index; Pre = pre-CPB; Post $=30 \mathrm{~min}$ post $-\mathrm{CPB} ; 12 \mathrm{hPO}=12 \mathrm{~h}$ postoperative $; 24 \mathrm{hPO}=$ $24 \mathrm{~h}$ postoperative

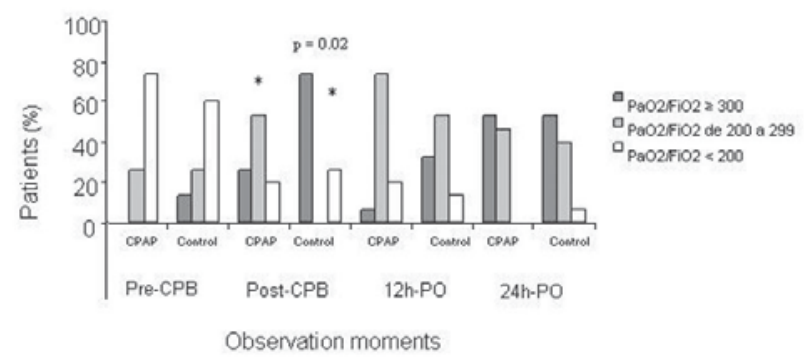

Fig. 4 - $\mathrm{PaO}_{2} / \mathrm{FiO}_{2}(\mathrm{mmHg})$ at different observation times in both groups. - Statistically significant difference was found in the percentage of patients that has shown $\mathrm{PaO}_{2} / \mathrm{FiO}_{2}$ between $200 \mathrm{e}$ 300 at Post-CPB in the CPAP group in relation to control group. (* $p=0.02) . C P B=$ cardiopulmonary bypass; Pre = pre-CPB; Post$C P B=30$ min post $-C P B ; 12 h P O=12 h$ postoperative $; 24-P O=$ 24h postoperative

\section{DISCUSSION}

CPAP group and control group were homogeneous in relation to demographic characteristics, $\mathrm{CPB}$ time and pulmonary gas exchange indexes at baseline (Pré-CPB) (Table 1), thus allowing a safe comparison of data obtained at different moments of the study protocol.

Pulmonary dysfunction induced by open heart surgery and $\mathrm{CPB}$ are quite common in the post-operative period at the ICU, and are characterized by increased intrapulmonary shunt, atelectasis, increased alveolar-arterial oxygen gradient, increased extra-vascular lung water and decreased pulmonary compliance [5]. The main causes of post-bypass pulmonary dysfunction are the reduced or absent blood flow through the lungs during $\mathrm{CPB}$ and the surgical opening of pleural cavity [4].

Weiss et al. [9] reported a decrease in $\mathrm{PaO}_{2} / \mathrm{FiO}_{2}$ during the first 12 hours post-CPB in patients submitted to coronary artery bypass grafting (CABG). In their study, $\mathrm{PaO}_{2} / \mathrm{FiO}_{2}$ was calculated just after anesthetic induction and was compared to the values obtained at one hour, six hours and 12 hours after $\mathrm{CPB}$ ending in 460 patients. The observed values of $\mathrm{PaO}_{2} / \mathrm{FiO}_{2}$ were; $224 \pm 109 \mathrm{mmHg}$; $284 \pm$ $104 \mathrm{mmHg}$; and $235 \pm 90 \mathrm{mmHg}$ (pre-CPB; one hour; six hours; and 12 hours post-CPB; respectively). The authors have concluded that, despite improvements in $\mathrm{CPB}$ techniques, the presence of hypoxemia remains still common in post-operative cardiac surgery patients.

According to Barbosa and Carmona [10], the worsening of $\mathrm{PaO}_{2} / \mathrm{FiO}_{2}$ in the postoperative period of CABG surgery is mainly due to the reduced pulmonary functional residual capacity secondary to the presence of microatelectasis, alterations in the pulmonary elastic properties and changes in the flow-resistive characteristics of the respiratory system, including its two components: lung and thoracic wall. These alterations lead to misdistribution of inspired gases, adversely affecting pulmonary gas exchange, with consequent hypoxemia. Additionally, CPB induces systemic inflammatory response syndrome (SIRS) and acute pulmonary lung injury, thus contributing to $\mathrm{PaO}_{2} / \mathrm{FiO}_{2}$ decrease.

In regard to the reliability of these traditional variables often used to evaluate patient's oxygenation, Terzi and Dragosavac [11] consider that $\mathrm{PaO}_{2} / \mathrm{FiO}_{2}$ and $\mathrm{P}(\mathrm{A}-\mathrm{a}) \mathrm{O}_{2}$ are straightly comparable when applied to post-operative patients submitted to open heart surgery with CPB. Indeed, in the present trial, $\mathrm{PaO}_{2} / \mathrm{FiO}_{2}$ has shown values inside the normal range at pre-CPB moment, and a subsequent decrease at the following observation moments $(p<0.001)$ (Table 2).

In our trial, $\mathrm{PaO}_{2} / \mathrm{FiO}_{2}$ has shown a tendency to be better in CPAP group compared to control only just after (30 minutes) CPB ( $256 \pm 83 \mathrm{mmHg} v$ s. $223 \pm 144 \mathrm{mmHg})$, but this improvement was not statistically significant $(\mathrm{p}=0.39)$ (Figure 3).

The alveolar-arterial oxygen gradient $\left[\mathrm{P}(\mathrm{A}-\mathrm{a}) \mathrm{O}_{2}\right]$ in patients with pulmonary gas exchange derangements will be increased at any range of $\mathrm{F}_{1} \mathrm{O}_{2}$, with greater values than those found in normal subjects. As reported by Terzi and Dragosavac [11], the calculated $\mathrm{P}(\mathrm{A}-\mathrm{a}) \mathrm{O}_{2}$ in post-operative period of patients submitted to cardiac surgery with $\mathrm{CPB}$ 
has shown values varying from $119 \mathrm{mmHg}$ with $\mathrm{FiO}_{2}=0.4$ to $338 \mathrm{mmHg}$ with $\mathrm{FiO}_{2}=1.0$.

Yamagishi et al. [12] reported, in 50 patients submitted to CABG, $\mathrm{P}(\mathrm{A}-\mathrm{a}) \mathrm{O}_{2}$ varying from $22 \mathrm{mmHg}$ to $118 \mathrm{mmHg}$ three hours after surgery, and a mean value of $121 \mathrm{~mm} \mathrm{Hg}$ at the first post-operative day. Similar results were found in our trial, where $\mathrm{P}(\mathrm{A}-\mathrm{a}) \mathrm{O}_{2}$ has shown increased values in both groups at all moments (Table 3 ).

Some protective therapeutic strategies has been proposed in the literature in aim to attenuate the pulmonary dysfunction frequently seen after cardiac surgery with CPB, including repeated vital capacity maneuvers [4], and the use of CPAP during CPB [5].

In the repeated vital capacity maneuver, the lungs are manual hyper-inflated with a pressure around $40 \mathrm{cmH}_{2} \mathrm{O}$ that are sustained for 15 seconds, just before CPB ending. This maneuver is indicated in specific cases where mechanical ventilation with high $\mathrm{FiO}_{2}$ is required [13]. In an experimental trial using pigs, Magnusson et al. [4] reported that atelectasis formation and intrapulmonary shunt could be avoided by applying the repeated vital capacity maneuver before CPB ending.

Magnusson et al. [8], in an experimental trial evaluating the effects of CPAP during CPB in order to avoid airway collapse, have applied CPAP at $5 \mathrm{cmH}_{2} \mathrm{O}$ in six pigs submitted to median sternotomy and CPB for 90 minutes. Ventilation-perfusion distribution was evaluated by the inert gas elimination technique, and computerized tomographic images were used to detect the presence of atelectatic lung areas. The authors have not observed statistically significant differences in the incidence of atelectasis or intrapulmonary shunt reduction and hypoxemia in the studied sample, thus concluding that in this swine model the formation of atelectasis is not effectively prevented by applying CPAP at $5 \mathrm{cmH}_{2} \mathrm{O}$ during CPB.

Clinically, some investigators have been evaluated the effects of CPAP applied during CPB on pulmonary gas exchange, and trying to correlate these early beneficial effects with respiratory function later on, but with conflicting results.

In this way, Berry et al. [2] have applied CPAP at $5 \mathrm{cmH}_{2} \mathrm{O}$ during $\mathrm{CPB}$ in patients submitted to open heart surgery and compared them to those whose airways remained open to the atmosphere. They have observed that $\mathrm{P}(\mathrm{A}-\mathrm{a}) \mathrm{O}_{2}$ was statistically lesser in CPAP group at 30 minutes post-CPB ending, but this beneficial effect has not been sustained four and eight hours after surgery. The authors concluded that no advantage is offered by the use of CPAP during CPB as a maneuver to improve postoperative pulmonary function.

Gilbert et. al. [7], in a similar trial, have applied low level of CPAP during CPB in nine patients submitted to cardiac surgery. They evaluated lung mechanical properties by measuring compliance and airway resistance, and the gas exchange function by calculating $\mathrm{P}(\mathrm{A}-\mathrm{a}) \mathrm{O}_{2}$. The authors reported that those patients who were protectively ventilated by applying CPAP at low levels have not shown significant changes in postoperative pulmonary mechanical properties or in $\mathrm{P}(\mathrm{A}-\mathrm{a}) \mathrm{O}_{2}$.

Otherwise, Zabeeda et al. [14] have compared the effects of high-frequency ventilation, volume controlled ventilation and $\mathrm{CPAP}$ at $5 \mathrm{cmH}_{2} \mathrm{O}$ during $\mathrm{CPB}$ in the postoperative pulmonary gas exchange in patients submitted to open heart surgery, showing that $\mathrm{P}(\mathrm{A}-\mathrm{a}) \mathrm{O}_{2}$ was lesser and $\mathrm{PaO}_{2}$ was higher in patients receiving CPAP when compared to those managed with the other two modes of mechanical ventilation strategies.

Loeckinger et al. [5] have applied CPAP at $10 \mathrm{cmH}_{2} \mathrm{O}$ during $\mathrm{CPB}$ in seven patients submitted to elective CABG surgery. Ventilation/perfusion distribution was evaluated by inert gas elimination technique and pulmonary gas exchange by $\mathrm{P}(\mathrm{A}-\mathrm{a}) \mathrm{O}_{2}$. The authors could observe that CPAP at 10 $\mathrm{cmH}_{2} \mathrm{O}$ has significantly improved pulmonary ventilation/ perfusion distribution, resulting in lesser intrapulmonary shunt four hours after CPB, when compared to patients whose airways remained open to room air. However, the authors also reported that these beneficial effects were not sustained from the fourth to the eighth hour after CPB.

Ishikawa et al. [15] have reported that CPAP at $5 \mathrm{cmH}_{2} \mathrm{O}$ applied just after pleurotomy prevents the deterioration of pulmonary gas exchange indexes and decreases atelectasis formation after CPB in patients submitted to cardiac surgery. However, the authors have also observed that these effects could no longer be sustained during post-operative recovery.

Koner et al. [16] evaluated the evolution of $\mathrm{P}(\mathrm{A}-\mathrm{a}) \mathrm{O}_{2}$ in 44 patients submitted to CABG surgery with CPB divided into three groups: Group 1, patients that has been mechanically ventilated during $\mathrm{CPB}$ with a tidal volume (TV) of $6 \mathrm{ml} / \mathrm{kg}$ and PEEP at $5 \mathrm{cmH}_{2} \mathrm{O}(\mathrm{n}=15)$; Group 2, ventilated with TV of $5 \mathrm{ml} / \mathrm{kg}$ and PEEP at $5 \mathrm{cmH}_{2} \mathrm{O}(\mathrm{n}=14)$; and Group 3 , patients that has been ventilated with TV of $10 \mathrm{ml} / \mathrm{kg}$, without PEEP (ZEEP). They reported better $\mathrm{P}(\mathrm{A}-\mathrm{a}) \mathrm{O}_{2}$ in Groups 1 and 2 (patients that used PEEP at $5 \mathrm{cmH}_{2} \mathrm{O}$ during CPB) when compared to group 3 (ZEEP).

Altmay et al. [17] have evaluated the effects of CPAP at $10 \mathrm{cmH}_{2} \mathrm{O}$ during $\mathrm{CPB}$ on pulmonary gas exchange after open heart surgery. They reported lesser values of intrapulmonary shunt and of $\mathrm{P}(\mathrm{A}-\mathrm{a}) \mathrm{O}_{2} 20$ minutes after $\mathrm{CPB}$ and just after sternum closure in those patients that have used CPAP during $\mathrm{CPB}$, when compared to those whose airways were kept open to atmosphere. They concluded that CPAP use during CPB is an effective maneuver to reduce intrapulmonary shunt and the $\mathrm{P}(\mathrm{A}-\mathrm{a}) \mathrm{O}_{2}$ just after surgery ending, but their beneficial effects were transient and couldn't be sustained for the whole postoperative period.

One important limitation of the present study is the small population sample. This number of patients was initially 
selected based on previously published papers [2,5,8]. Just after the inclusion of the first 30 patients in the trial a preliminary statistical analysis of the data was done, and a projection indicated that even if the population sample had been increased to 100 or 150 patients, clinically significant or relevant differences could not be found between patients receiving or not CPAP during CPB. In this way, we decided to stop the trial.

In summary, in accordance with many other literature reports, we were unable to demonstrate that applying CPAP during $\mathrm{CPB}$ in open heart surgery results in prolonged beneficial effects on postoperative pulmonary gas exchange.

\section{CONCLUSION}

Continuous positive airway pressure at $10 \mathrm{cmH}_{2} \mathrm{O}$ administered during $\mathrm{CPB}$, although had lightly improved $\mathrm{PaO}_{2} / \mathrm{FiO}_{2}$ at 30 minutes post-CPB, had no significant sustained effect on postoperative pulmonary gas exchange. We concluded that in patients submitted to myocardial revascularization, application of $10 \mathrm{cmH}_{2} \mathrm{O}$ CPAP does not improve postoperative pulmonary gas exchange.

\section{REFERENCES}

1. Andrejaitiene J, Sirvinskas E, Bolys R. The influence of cardiopulmonary bypass on respiratory dysfunction in early postoperative period. Medicina (Kaunas). 2004;40(Suppl 1):7-12.

2. Berry CB, Butler PJ, Myles PS. Lung management during cardiopulmonary bypass: is continuous positive airways pressure beneficial? Br J Anaesth. 1993;71(6):864-8.

3. Dyhr T, Laursen N, Larsson A. Effects of lung recruitment maneuver and positive end-expiratory pressure on lung volume, respiratory mechanics and alveolar gas mixing in patients ventilated after cardiac surgery. Acta Anaesthesiol Scand. 2002;46(6):717-25.

4. Magnusson L, Wicky S, Tydén H, Hedenstierna G. Repeated vital capacity manoeuvres after cardiopulmonary bypass: effects on lung function in a pig model. $\mathrm{Br} \mathrm{J}$ Anaesth. 1998;80(5):682-4.

5. Loeckinger A, Kleinsasser A, Lindner KH, Margreiter J, Keller C, Hoermann C. Continuous positive airway pressure at 10 cm H2O during cardiopulmonary bypass improves postoperative gas exchange. Anesth Analg. 2000;91(3):522-7.
6. Bonassa J. Princípios básicos dos ventiladores artificiais. In: Carvalho CRR, editor. Ventilação mecânica. São Paulo:Atheneu;2000. v.2, p.101-36.

7. Gilbert TB, Barnas GM, Sequeira AJ. Impact of pleurotomy, continuous positive airway pressure, and fluid balance during cardiopulmonary bypass on lung mechanics and oxygenation. J Cardiothorac Vasc Anesth. 1996;10(7):844-9.

8. Magnusson L, Zemgulis V, Wicky S, Tydén H, Hedenstierna G. Effect of CPAP during cardiopulmonary bypass on postoperative lung function. An experimental study. Acta Anaesthesiol Scand. 1998;42(10):1133-8.

9. Weiss YG, Merin G, Koganov E, Ribo A, Oppenheim-Eden A, Medalion B, et al. Postcardiopulmonary bypass hypoxemia: a prospective study on incidence, risk factors, and clinical significance. J Cardiothorac Vasc Anesth. 2000;14(5):506-13.

10. Barbosa RAG, Carmona MJC. Avaliação da função pulmonar em pacientes submetidos à cirurgia cardíaca com circulação extracorpórea. Rev Bras Anestesiol. 2002;52(6):689-99.

11. Terzi RGG, Dragosavac D. Monitorização do intercâmbio gasoso pulmonar no paciente submetido à ventilação mecânica. In: Carvalho CRR, editor. Ventilação mecânica. São Paulo:Atheneu;2000. v.1. p.199-204.

12. Yamagishi T, Ishikawa S, Ohtaki A, Takahashi T, Koyano T, Ohki S, et al. Postoperative oxygenation following coronary artery bypass grafting. A multivariate analysis of perioperative factors. J Cardiovasc Surg (Torino). 2000;41(2):221-5.

13. Oczenski W, Schwarz S, Fitzgerald RD. Vital capacity manoeuvre in general anaesthesia: useful or useless? Eur J Anaesthesiol. 2004;21(4):253-9.

14. Zabeeda D, Gefen R, Medalion B, Khazin V, Shachner A, Ezri $\mathrm{T}$. The effect of high-frequency ventilation of the lungs on postbypass oxygenation: A comparison with other ventilation methods applied during cardiopulmonary bypass. J Cardiothorac Vasc Anesth. 2003;17(1):40-4.

15. Ishikawa S, Ohtaki A, Takahashi T, Sakata K, Koyano T, Kano M, et al. PEEP therapy for patients with pleurotomy during coronary artery bypass grafting. J Card Surg. 2000;15(3):175-8.

16. Koner O, Celebi S, Balci H, Cetin G, Karaoglu K, Cakar N. Effects of protective and conventional mechanical ventilation on pulmonary function and systemic cytokine release after cardiopulmonary bypass. Intensive Care Med. 2004;30(4):620-6.

17. Altmay E, Karaca P, Yurtseven N, Ozkul V, Aksoy T, Ozler A, et al. Continuous positive airway pressure does not improve lung function after cardiac surgery. Can J Anesth. 2006;53(9):919-25. 